\title{
2 Emma Goldman's Identity: Anarchist, Anarcha-Feminist, Publicist, and Revolutionary
}

Emma Goldman was not only what American Studies scholar Marian J. Morton called "a woman without a country"1 or a woman who lived an "intense and fast-paced" life, she was also an activist, dedicating her life, especially her years in the United States, ${ }^{3}$ to the fight for equality in all possible senses of the word. In addition, Goldman was one of the many Jewish immigrants who reached the shores of the "New World" and dedicated her life to a form of politically left radicalism, i.e. anarchism, which was particularly attractive and convincing for them, as they had suffered greatly from economic exploitation and social ostracism. ${ }^{4}$ At the same time, these women and men not only turned towards radical thoughts, but they also abandoned their Jewish heritage and cut off their ties to their religious tradition. ${ }^{5}$ Goldman, however, like many others, kept this identity, and, as Gerald Sorin remarks, "her commitment to anarchism did not divert her from speaking and writing, openly and frequently, about the particular burdens Jews face in a world in which antisemitism was a living enemy." ${ }^{\prime 2}$ Naturally, Goldman's personal experiences impacted on her political life, often directing it towards a specific direction, or, as Viviann Gornick put it, "[r]adical politics for her was, in fact, the history of one's own hurt, thwarted, humiliated feelings at the hands of institutionalized authority." For Goldman, anarchism would therefore be more of a "protean experience ... a posture, an attitude, a frame of mind and spirit" ${ }^{8}$ that she continuously linked to the problems of her time, which in a way reflected her own problems with the American state

1 Marian J. Morton, Emma Goldman and the American Left: "Nowhere at Home" (New York: Twaynne, 1992), viii.

2 Wexler, Emma Goldman, xv.

3 Claire Goldstene, The Struggle for America's Promise: Equal Opportunity at the Dawn of Corporate Capital (Jackson, MS: University of Mississippi Press, 2014), 69-98.

4 This interelationship between Jewishness and political radicalism is discussed in more detail in Sebastian Kunze and Frank Jacob, "Introduction: Thoughts on Jewish Radicalism as a Phenomenon of Global Modernity," in Jewish Radicalisms: Historical Perspectives on a Phenomenon of Global Modernity, ed. Frank Jacob and Sebastian Kunze (Berlin: De Gruyter, 2019), 1-20.

5 Guttmann, "Jewish Radicals, Jewish Writers," 563.

6 Sorin, The Prophetic Minority, 8. Sorin consequently further remarks that Goldman's "faith in anarchism, with its emphasis on universalism, did not result from and was not dependent on a casting off of Jewish identity.” Ibid.

7 Gornick, Emma Goldman, 4.

8 Ibid.

Ә OpenAccess. () 2020 Frank Jacob, published by De Gruyter. (cc) BY-NC-ND This work is licensed under the Creative Commons Attribution-NonCommercial-NoDerivatives 4.0 License. 
and its society, the two things she regularly struggled with. ${ }^{9}$ One can also argue, as Kathy E. Ferguson correctly did, that Goldman was as much a product of the United States' public mind, especially since the latter was threatened by the radicalism she represented. The famous anarchist "was largely a product of the dominant intersecting systems of criminal, medical, and media technologies; her presence in public life was construed primarily within the discourses of danger they generated." 10

Goldman was somebody who continuously attacked the existent order, and thereby often accepted the danger her speeches and writings would impose on her personal life. Her "anarchist parrhesia"11 steadily "combined frontal assault with carefully calculated rhetorical arts and tactical silences,"12 but this strategy would also lead the authorities to consider Goldman as one of the most dangerous radicals in the country. In particular, the head of the General Intelligence Division of the Department of Justice, the young J. Edgar Hoover (1895-1972), had developed a personal hatred for Goldman and would later not only prepare a legal move against her and Alexander Berkman ${ }^{13}$ but also cooperate with Attorney General A. Mitchell Palmer (1872-1936) to get rid of her to make America a safer place. However, it was not only Hoover and the US authorities Goldman had to worry about; during her life, she would also be observed by the governments of several other countries, including Britain, Germany, and even the Soviet Union. ${ }^{14}$ Even beyond her steady fight against governments around the world, Goldman's life is, in a way, outstanding. The famous anarchist also tried to present this life in her autobiography Living My Life (1931), which Candace Falk referred to as a "passionate memoir of a great woman in the history of America's radicalism." Although "the autobiography stops short of serious self-criticism" and often leaves out critical self-reflection because Goldman "wanted to be seen

9 For a good survey of Goldman's main struggles during her American years, see ibid., 6-91. 10 Kathy E. Ferguson, “Discourses of Danger: Locating Emma Goldman,” Political Theory 36, no. 5 (2008): 737.

11 Ibid., 738. Ferguson here refers to Foucault, who identified parrhesia as "a verbal activity in which a speaker expresses his personal relationship to truth, and risks his life because he recognizes truth-telling as a duty to improve or help other people (as well as himself).” Michel Foucault, Fearless Speech, ed. Joseph Pearson (Los Angeles: Semiotext(e), 2001), 19.

12 Ferguson, "Discourses of Danger," 738.

13 For the information Hoover had collected on the anarchists, see FBI File on Emma Goldman and Alexander Berkman Archives, IISH, ARCH01724.

14 Ferguson, "Discourses of Danger," 739.

15 Candace Falk, "Introduction," in Emma Goldman, Living My Life: An Autobiography (Salt Lake City, UT: Peregrine Smith, 1982 [1931]), vii. 
as a great example whose bravery and consistency would inspire others," 16 it is an important historical document that provides a deep insight into American history at the end of the 19th and beginning of the 20th century in general, and of the American as well as international anarchist movements in particular. Regardless of the lack of self-criticism by Goldman, the autobiography truly describes the genesis and experiences of “[one] of the century's most renowned cultural and political leaders," ${ }^{17}$ who nevertheless united multiple different identities in one life. From the early 1890s, Goldman was a public figure and a wellknown radical, and in the early 1900s she would lecture in many US cities, where the anarchist not only talked about her political ideas but also discussed topics like "free love, the drama, birth control, patriotism, militarism, women's emancipation, education, and free speech."18

Considering these multiple perspectives of Goldman's activity, it is hardly sufficient to simply consider her to be an anarchist. American historian Ann Uhry Abrams highlighted this complexity of the famous anarchist by referring to her as "the prototypical moral and political renegade, intense, out spoken and intolerant." ${ }^{19}$ In fact, Goldman seemed to be "an omnipresent spokeswoman, organizer, and supporter" ${ }^{20}$ who would stand up against any form of injustice, fight against any sign of inequality, and demand freedom for women, workers, and humanity as a whole. The present chapter will try to link these different identities while discussing Goldman's political development until the outbreak of the First World War in 1914. Her radicalism was the result of a conglomerate of sources that needs to be understood as such. One source for her radicalism is not enough, and Goldman surely deserves multiple emblems of radical activism. She was not only an immigrant, an anarchist, a feminist, or a revolutionary. She was all that at once, although some of these identities might have been more obvious than others at different moments of her life. However, to understand Goldman means to understand and to accept this complexity of her different identities. Before we can discuss the revolutionary Goldman in more detail, therefore, it is important to approach her other identities first, as they will be helpful for a better understanding of the anarchist's theoretical interpretation of an anticipated revolution that would eventually, or at least supposedly, free the whole of hu-

16 Ibid., viii.

17 Ann Uhry Abrams, “The Ferrer Center: New York's Unique Meeting of Anarchism and the Arts," New York History 59, no. 3 (1978): 306.

18 Falk, "Introduction," vii.

19 Abrams, "The Ferrer Center," 309.

20 Auleta and Goldstone, "happy birthday, emma," 2. 
manity from suppression, injustice, and inequality, i.e. the things that bothered the anarchist intellectual the most.

Goldman was born in the Russian Empire in 1869-in Kovno, present-day Kaunas in Lithuania-as an "unwanted child of a poor Jewish family"21 and "suffered severe beatings from her father as a young child." 22 When she later emigrated, she did it in part because she broke with an orthodox Jewish life, her parents and the Russian Empire, maybe even because the later radical, "[e]ven as a young girl, ... manifested a rebellious and sturdy nature." ${ }^{23}$ When the family moved to St. Petersburg in 1882, Goldman not only got in contact with contemporary Russian literature but also with radical thoughts for the first time, as the populist and nihilist movements criticized the Czarist order, often using violence as their means as well. ${ }^{24}$ In the United States, the young emigrant hoped to find a new life, only determined by American values, especially liberty, and the pursuit of happiness. ${ }^{25}$ She was accompanied by her sister Helena (1860-1920), with whom the later anarchist started her life in the US garment industry, where so many Jewish-Russian immigrants ended up after having crossed the Atlantic. In 1887, she married Jacob Kershner, also a Jewish immigrant, who lived in Rochester, New York. After two years, however, Goldman left him and settled in New York City, where she would be further radicalized due to her experiences in the needle trade of the US metropolis. ${ }^{26}$ There, her early identity as an anar-

21 Rich and Smith, Rhetoric of Revolution, 61.

22 Sorin, The Prophetic Minority, 38. On Goldman's childhood, see also Wexler, Emma Goldman, $3-19$.

23 Rich and Smith, Rhetoric of Revolution, 62. See also Kowal, "Anarcha-Feminism,” 273.

24 Auleta and Goldstone, "happy birthday, emma," 2; Edward de Grazia, "The Haymarket Bomb," Law and Literature 18, no. 3 (2006): 291; Morton, Emma Goldman, 1-14; Rich and Smith, Rhetoric of Revolution, 61-62. On Russian populism and nihilism, see Christopher Ely, Underground Petersburg: Radical Populism, Urban Space and the Tactics of Subversion in Reform-Era Russia (DeKalb: NIU Press, 2016); Derek Offord, The Russian Revolutionary Movement in the 1880s (Cambridge: Cambridge University Press, 1986); Philip Pomper, The Russian Revolutionary Intelligentsia (New York: Thomas Y. Crowell, 1970); Adam B. Ulam, In the Name of the People: Prophets and Conspirators in Prerevolutionary Russia (New York: Viking Press, 1977); Franco Venturi, Roots of Revolution: A History of the Populist and Socialist Movements in 19th Century Russia (London: Phoenix, 2001); Astrid Von Borcke, "Violence and Terror in Russian Revolutionary Populism: The Narodnaya Volya, 1879-83," in Social Protest, Violence and Terror in Nineteenth-and Twentieth-century Europe, ed. Gerhard Hirschfeld and Wolfgang J. Mommsen (New York/London: Palgrave Macmillan, 1982), 48-62.

25 Auleta and Goldstone, "happy birthday, emma," 2.

26 Kowal, “Anarcha-Feminism,” 274; Bill Lynskey, “'I Shall Speak in Philadelphia': Emma Goldman and the Free Speech League,” The Pennsylvania Magazine of History and Biography 133, no. 2 (2009): 173. 
chist and a well-known lecturer was developed by her contact with Alexander Berkman, who would not only initially become Goldman's lover, but would also remain her lifelong friend and companion in later years. She shared an "enthusiasm for social justice"27 with Berkman, and this would also lead her into the anarchist world of "Radical Gotham" ${ }^{28}$ of the 1880s, where radical German, ${ }^{29}$ Italian, ${ }^{30}$ and Jewish-Russian ${ }^{31}$ milieus would provide quite a broad sphere of radical experiences and activism alike.

It was especially the anarchists, whom Goldman got in contact with very quickly, who were the ones who pointed the finger at the hypocrisy of the American dream, which was only achievable for those who exploited their fellow immigrants. The anarchists, as historian Blaine McKinley put it, were women and men who were "[l]iving and thinking beyond convention, they offered a unique viewpoint on their times and experienced tensions that illuminated American society. Uncomfortable with the present, they remained torn between the simpler past and the possible future." 32 As mentioned above, many of these anarchists belonged to the radical immigrant communities of New York City, but there were also "Americans who had roots in abolitionism, free thought, and the labor movement, and who [like their immigrant comrades] were troubled by the economic inequalities, centralized power, and mass society they saw arising

27 William O. Reichert, “Toward a New Understanding of Anarchism," The Western Political Quarterly 20, no. 4 (1967): 861.

28 Tom Goyens, ed., Radical Gotham: Anarchism in New York City from Schwab's Saloon to Occupy Wall Street (Urbana, IL: University of Illinois Press, 2017).

29 Tom Goyens, Beer and Revolution: The German Anarchist Movement in New York City, 18801914 (Urbana, IL: University of Illinois Press, 2007); Tom Goyens, "Johann Most and the German Anarchists," in Radical Gotham: Anarchism in New York City from Schwab's Saloon to Occupy Wall Street, ed. Tom Goyens (Urbana, IL: University of Illinois Press, 2017), 12-32.

30 Philip Cannistraro and Gerald Meyer, eds., The Lost World of Italian-American Radicalism (Westport, CT: Praeger Publishers, 2003); Marcella Bencivenni, Italian Immigrant Radical Culture: The Idealism of the Sovversivi in the United States, 1890-1940 (New York: New York University Press, 2011).

31 Steven Cassedy, To the Other Shore: The Russian Jewish Intellectuals Who Came to America (Princeton, NJ: Princeton University Press, 2014); Kenyon Zimmer, Immigrants against the State: Yiddish and Italian Anarchism in America (Urbana, IL: University of Illinois Press, 2015); Kenyon Zimmer, "Saul Yanovsky and Yiddish Anarchism on the Lower East Side," in Radical Gotham: Anarchism in New York City from Schwab's Saloon to Occupy Wall Street, ed. Tom Goyens (Urbana, IL: University of Illinois Press, 2017), 33-53.

32 Blaine McKinley, “'The Quagmires of Necessity': American Anarchists and Dilemmas of Vocation,” American Quarterly 34, no. 5 (1982): 503-504. See also Blaine McKinley, “Anarchist Jeremiads: American Anarchists and American History,” The Journal of American Culture 6, no. 2 (1983): $75-84$. 
at the expense of local self-sufficiency and personal initiative."33 The anarchist movement in its US and urban context was consequently international, and the languages of radicalism there ranged from German, Italian and Russian to Yiddish, and Goldman would later lecture in three of them, besides addressing audiences in English as well. Anarchists came from all kinds of professions, and next to wage laborers, there were those who were active in the skilled trades, such as printing, or professions like medicine or law. Others found their way into sales and commissions jobs, and a relatively limited minority "made their living through proselytizing for anarchism." ${ }^{34}$ Goldman would eventually become one of the latter, although it was a long time before she was eventually able to live off her radicalism, and this only for a few years before her activities made the US authorities deport her from her country of choice.

\section{The Anarchist}

Like many of her comrades, Goldman had hoped to find a better life in the US, ${ }^{35}$ but the garment industry opened her eyes. In the American factories, workers were steadily exploited and were only just able to stay alive. This injustice and systematic inequality sparked Goldman's resistance against capitalism and the state, which the female immigrant experienced as "be[ing] everywhere and at all times an instrument of oppression and psychological trauma." ${ }^{36}$ What Candace Falk called Goldman's “political birth"37 eventually followed in 1887 in the aftermath of the Haymarket Tragedy. It was her "strong emotional reaction to the execution of the Haymarket anarchists" 38 that made her look for political alternatives to a state that would murder its own people. In 1889, almost two years after the events, Goldman still could not sleep due to thinking about this tragedy, and she describes her feelings in more detail in her autobiography.

That night I could not sleep. Again I lived through the events of 1887. Twenty-one months had passed since the Black Friday of November 11, when the Chicago men had suffered their martyrdom, yet every detail stood out clear before my vision and affected me as if it had happened but yesterday. My sister Helena and I had become interested in the fate of the men during the period of their trial. The reports in the Rochester newspapers irritat-

33 McKinley, “The Quagmires of Necessity,” 504.

34 Ibid., 505.

35 Martha Solomon, Emma Goldman (Boston, MA: Twayne Publishers, 1987), 3.

36 Ray, "No License to Serve," 11.

37 Falk, "Introduction," vii.

38 Solomon, Emma Goldman, 1. 
ed, confused, and upset us by their evident prejudice. The violence of the press, the bitter denunciation of the accused, the attacks on all foreigners, turned our sympathies to the Haymarket victims. ${ }^{39}$

This experience came in combination with a life that for Russian-Jewish immigrants was hardly different from their life under the yoke of the Czar. ${ }^{40}$ For any of these immigrants, the realities of capitalist exploitation in the United States were as severe as their previous life in Russia had been, and as Goldman emphasized, "There [in Russia] [the immigrant] must work like a galley slave whether he will or no. Here he is free-free to starve, free to be robbed and swindled on every hand. But the moment he seeks to organize labor, or assert his rights or strike for the defense of his dearest interests he is no longer free, but is apprehended and thrown in prison." ${ }^{41}$

The Haymarket Tragedy evoked Goldman's interest not only in the victims' stories but also in the political ideas they represented. In New York, she then began to become active in the anarchist circles around the German immigrant Johann Most (1846-1906), who would mentor her during her first anarchist activities. ${ }^{42}$ Most, the editor of the German anarchist paper Die Freiheit, was referred to by the Pittsburgh Post as "the king bee of anarchists" 43 on New York City's Lower East Side. The German immigrant and well-known anarchist "could electrify audiences with his fiery oratory," ${ }^{44}$ and he almost naturally became Goldman's idol. At the same time, he realized the latter's talent and encouraged her to speak in public. Not long after, the young woman was one of "the newly converted who became enthusiastic proclaimers of the anarchist world-

39 Emma Goldman, Living My Life (New York: Knopf, 1931), ch. 1. Accessed December 17, 2018. https://theanarchistlibrary.org/library/emma-goldman-living-my-life.

40 “A Woman Anarchist," Pittsburgh Leader, November 22, 1896, in Emma Goldman: A Documentary History of the American Years, vol. 1: Made for America, 1890-1901, ed. Candace Falk et al. (Urbana, IL: University of Illinois Press, 2008), 243-244.

41 Ibid., 244.

42 Kowal, "Anarcha-Feminism," 274; Rocker, "Zum Geleit," 3-4; Solomon, Emma Goldman, 4-8. In Chapter 1 in Living My Life, Goldman wrote that she intentionally met with Most, whose German paper Die Freiheit she had read and whose articles about the events in Chicago must have inspired her: "My mind was made up. I would go to New York, to Johann Most. He would help me prepare myself for my new task."

43 “Goldman's Cry Against Society," Pittsburgh Post, November 27, 1896, in Emma Goldman: A Documentary History of the American Years, vol. 1: Made for America, 1890-1901, ed. Candace Falk et al. (Urbana, IL: University of Illinois Press, 2008), 250. Also see Kowal, “Anarcha-Feminism," 274.

44 Lynskey, "I Shall Speak in Philadelphia," 174. 
view." 45 The talented young woman soon "enjoyed a notoriety unequalled by any other woman in American public life," 46 a status constantly kept alive by Goldman's involvement in acts of anarchist protest and the reports by the American press that kept her image vivid for the American public. She became involved, politically and emotionally, with Alexander Berkman, ${ }^{47}$ who in 1892 attempted, with two other young anarchists, to assassinate the industrialist Henry Clay Frick (1849-1919), ${ }^{48}$ the man responsible for the use of violence against workers who striked at the Carnegie Steel Mills in Homestead, Pennsylvania during the Homestead Strike earlier that year. ${ }^{49}$ Berkman's attempt failed, and he was sent to prison for the following 14 years, although he had originally been sentenced to $22 .{ }^{50}$ For Goldman, the motivation for the assassination was Berkman's "belief that if the capitalists used Winchester rifles and bayonets on workingmen they should be answered with dynamite." ${ }^{51}$ At the same time, Frick had aroused Goldman's anger, especially because of his "dictum to the workers: he would rather see them dead than concede to their demands, and he threatened to import Pinkerton detectives. The brutal bluntness of the account, the inhumanity of Frick towards the evicted mother, inflamed my mind. Indignation swept my whole being." 52 Her struggle against industrialists like Frick was consequently more than natural and a consequence of Goldman's "strong social instinct" and her wish for a better, less exploitative world. The anarchist Goldman, however, was not in favor of violent methods, but considered them to be an expression of society's inequalities, or, as William O. Reichert formulated it, "Social violence, she argued, will naturally disappear at the point at which men have

45 Rocker, "Zum Geleit," 4. On Most's influence and relationship with Goldman, see also de Grazia, "The Haymarket Bomb,” 296; Rabin, "The Advent of a Western Jewess," 121; Reichert, "Toward a New Understanding of Anarchism," 861;

46 Wexler, Emma Goldman, xv.

47 Guttmann, "Jewish Radicals," 564.

48 Ferguson, "Discourses of Danger," 744. On Frick, see Kenneth Warren, Triumphant Capitalism: Henry Clay Frick and the Industrial Transformation of America (Pittsburgh, PA: University of Pittsburgh Press, 1996); Quentin R. Skrabec, Henry Clay Frick: The Life of the Perfect Capitalist (Jefferson, NC: McFarland, 2010).

49 Paul Krause, The Battle for Homestead, 1890-1892: Politics, Culture, and Steel (Pittsburgh, PA: University of Pittsburgh Press, 1992).

50 Alexander Berkman, Prison Memoirs of an Anarchist (New York: Mother Earth, 1912). Released from prison in 1906, Berkman would join forces with Goldman again in their anarchist struggle for a better society. See Alexander Berkman, “A Greeting," Mother Earth 1, no. 4 (1906). Accessed September 1, 2020. http://dwardmac.pitzer.edu/Anarchist_Archives/goldman/ ME/mev1n4.html.

51 “Goldman’s Cry Against Society,” 249.

52 Goldman, Living My Life, ch. 8. 
learned to understand and accommodate themselves to one another within a dynamic society which truly values human freedom."53 While Goldman had not been involved in the assassination attempt in 1892, it would not be long before she shared Berkman's fate, and she was sentenced too in 1893.

Due to one of her speeches on New York's Union Square on 21 August 1893, which, according to Rudolf Rocker, led to an anti-anarchist and anti-Goldman campaign in the city's capitalist press, ${ }^{54}$ she was arrested and sentenced and had to spend one year at Blackwell's Island Penitentiary, ${ }^{55}$ because it was argued that she had motivated workers to react violently against their capitalist exploitation. ${ }^{56}$ She had heard about the place from Most, who had also spent some time there before, but when Goldman actually arrived, the reality was something of a shock, regardless of how much she had thought herself to be prepared to go to prison for her convictions: "I knew from what Most had related to me about Blackwell's Island that the prison was old and damp, the cells small, without light or water. I was therefore prepared for what was awaiting me. But the moment the door was locked on me, I began to experience a feeling of suffocation. In the dark I groped for something to sit on and found a narrow iron cot. Sudden exhaustion overpowered me and I fell asleep." 57 Regardless of the hardships, Goldman survived, and the prison sentence as well as her related experiences "only enhanced her celebrity." 58 When Goldman left prison in 1894, around 2,800 people had gathered in New York to give her a warm welcome. She had become a celebrity and, as such, she could tour the country and attract many people to her lectures. ${ }^{59}$ The lectures were, in many American cities that had smaller anarchist groups, events that energized the discourse as well as awareness about anarchist ideas, while Goldman was able to use her popularity to spread her views on anarchism and other topics. The famous anarchist was, however, not only perceived as such, but her public image was built on her identity as a Jewish immigrant woman as well.

53 Reichert, “Toward a New Understanding of Anarchism,” 862.

54 Rocker, "Zum Geleit," 5.

55 Goldman describes her experiences there in Living My Life, ch. 12. The anarchist Philip Grosser (1890 -1933), who would be sentenced to prison and spent time at Blackwell's Island Penitentiary during the First World War, would later refer to it as "Uncle Sam's Devil's Island." Philip Grosser, Uncle Sam's Devil's Island: Experiences of a Conscientious Objector in America during the World War (Boston, MA: Excelsior Press, 1933).

56 Lynskey, "I Shall Speak in Philadelphia,” 175.

57 Goldman, Living My Life, ch. 12.

58 Lynskey, "I Shall Speak in Philadelphia,” 175.

59 Rabin, "The Advent of a Western Jewess," 122. 
The journalists that met her or interviewed her were always surprised that Goldman matched existent stereotypes about her so little. The "petite, blonde, good looking woman, to whom a pair of spectacles give a professional look" 60 was surprisingly nice and did not "look like a Russian Nihilist who will be sent to Siberia if she ever crosses the frontier of her native land." 61 Another reporter described her in the following way: she had "quite a pretty head ... crowned with soft brown hair, combed with a band and brushed to one side. Her eyes are the honest blue, her complexion clear and white. Her nose though rather broad and of a Teutonic type, was well formed. She is short of stature, with a well-rounded figure. Her whole type is more German than Russian." 62 The newspaper people Goldman met for the first time would regularly be surprised that the "queen of anarchists" was "in every sense a womanly looking woman, with masculine mind and courage." 63 The "short and rather good-looking young woman, whose deep grey eyes and gold eyeglasses give her a decided air of intellectuality and finesse," ${ }^{64}$ consequently often surprised her interviewers in many ways. This surprise was a consequence of Goldman's mismatch with common stereotypes of her time. Kathy E. Ferguson highlighted correctly that, in the late 1800 s and early 1900s,

[p]ublic expectations of large, masculinized, uncontrolled females, tastelessly attired, merged with anti Semitic presumptions about "dirty Jews" and nativist prejudices against "unwashed foreigners." Over and over, reporters were surprised that she was not hideous, and took care to reassure readers that she was small (4 feet, 10 1/2 inches, according to her Philadelphia police report), attractive, intelligent, well-dressed, soft-spoken, earnest. ${ }^{65}$

Considering these stereotypes, however, the steady reports about Goldman's personality, character, and appearance did not seem to confirm "the aura of menace" 66 that surrounded her. The female anarchist became a well-known figure in the United States, and it was her fame that would eventually link her to anarchist acts that she was not even personally involved in.

60 “Goldman's Cry Against Society,” 247.

61 Emma Goldman, "What Is There in Anarchy for Woman?" St. Louis Post-Dispatch Sunday Magazine, October 14, 1897: 9, in Emma Goldman: A Documentary History of the American Years, vol. 1: Made for America, 1890-1901, ed. Candace Falk et al. (Urbana, IL: University of Illinois Press, 2008), 289.

62 Ibid., 290.

63 Ibid., 292.

64 "A Woman Anarchist," 243.

65 Ferguson, "Discourses of Danger," 740.

66 Ibid., 743. 
It was the assassination of US President William McKinley (1843-1901) that provoked a strong anti-anarchist reaction by the state, and Goldman, who by then had replaced Most as the figurehead of the American anarchists, became one of the state enemies. Leon Czolgosz (1873-1901), McKinley's Polish-American anarchist assassin who was executed in late October 1901, said, according to an article in the New York Times, that he had killed the president because McKinley was an enemy of the "good working people. ${ }^{67}$ Earlier, the young anarchist had claimed to be a disciple of Goldman, although the two had only briefly met when she gave one of her speeches. ${ }^{68}$ The assassination, however, led to a public outcry that amalgamated the foreignness of immigrant communities and political radicalism and accused the state of not treating dangerous individuals like Goldman properly. Consequently, the government tried to use all legal possibilities at hand to contain the spread of anarchist ideas in the future, and anarchism as such became an emblematic turn that evoked ideas of dynamite and violence. ${ }^{69}$ There had actually been two different types of anarchists: some more philosophical, others rather violent, especially with regard to the idea of the so-called "propaganda of the deed," 70 a concept within the anarchist movement that was intensely discussed but also led to numerous assassinations between the mid-1860s and early 1930s. The US government and public had obviously been unaware of a real menace that did not just threaten European monarchs: "While many Americans considered anarchism a foreign problem and the United States immune from the litany of anarchist assassinations of European leaders and monarchs in the 1890s, President McKinley's assassination pulled the United States into existing international efforts and the global conversation about how to combat anarchist violence."71 And, regardless of the fact that the majority of anarchists were philosophical rather than violent, after 1901, anarchists would always be subject to general suspicions of planning an assassination or building a bomb to attempt one. In addition, the press contin-

67 “Assassin Czolgosz Is Executed at Auburn,” New York Times, October 30, 1901. See also Scott Miller, The President and the Assassin: McKinley, Terror, and Emire at the Dawn of the American Century (New York: Random House, 2011).

68 Julia Rose Kraut, "Global Anti-Anarchism: The Origins of Ideological Deportation and the Suppression of Expression,” Indiana Journal of Global Legal Studies 19, no. 1 (2012): 170.

69 Ibid., 171.

70 For the European perspective, see Heinz-Gerhard Haupt, Den Staat herausfordern: Attentate in Europa im späten 19. Jahrhundert (Frankfurt am Main/New York: Campus, 2019), 151-155. For the discourse within the anarchist movement, see Mitchell Abidor, Death to Bourgeois Society: The Propagandists of the Deed (Oakland, CA: PM Press, 2016); Philippe Kellermann, ed., Propaganda der Tat: Standpunkte und Debatten (1877-1929) (Münster: Unrast Verlag, 2016).

71 Kraut, “Global Anti-Anarchism,” 171. 
ued to consider anarchism a foreign problem and, in the case of Czolgosz, who was born in Detroit, Michigan, the newspapers continued to emphasize the immigrant identity of his Polish parents. ${ }^{72}$ McKinley's violent death marked the beginning of a serious conflict between the US state and the anarchists who lived within its borders. Existent laws were applied to raid anarchist meetings, intervene in lectures, and prohibit the circulation of anarchist publications, like journals or pamphlets. ${ }^{73}$ Goldman, as mentioned before, considered violence as an act taken by suffering people who had no other way to express or protest against their own misery. ${ }^{74}$ Goldman's text "What I Believe" $(1908)^{75}$ seems to offer some insight into her views on anarchism and society. It will therefore be taken into closer consideration here in order to better understand Goldman and to go beyond her public perception of an anarchist in the United States.

According to Goldman, anarchism "is a conspicuous protest of the most militant type. It is so absolutely uncompromising, insisting and permeating a force as to overcome the most stubborn assault and to withstand the criticism of those who really constitute the last trumpets of a decaying age.” The future belonged to anarchism, or more accurately, to an anarchist society in which the state would no longer control the people, but in which they would organize themselves. In such a society, the famous anarchist continues, there would be no place for property, which "means dominion over things and the denial to others of the use of those things." The existence of property, in combination with the commodification of human labor, "condemns millions of people to be mere nonentities, living corpses without originality or power of initiative, human machines of flesh and blood, who pile up mountains of wealth for others and pay for it with a gray, dull and wretched existence for themselves." Goldman consequently argues that "real wealth, social wealth" could not be achieved as long the lives of human beings needed to be exploited to create it. She consequently believed that "[a]narchism is the only philosophy that can and will do away with this humiliating and degrading situation." Only true freedom would give humanity the possibility to evolve, to develop, and to outgrow the evils of exploitation, especially with regard to work. According to Goldman, only "a society based on voluntary co-operation of productive groups, communities and societies loosely federated together, eventually developing into a free communism, actuated by a

72 Ibid., $174-175$.

73 Ibid., 176.

74 Reichert, "Toward a New Understanding of Anarchism," 861.

75 Emma Goldman, “What I Believe,” New York World, July 19, 1908. Accessed September 1, 2020. http://dwardmac.pitzer.edu/anarchist_archives/goldman/whatibelieve.html. The following quotes are taken from this text as well. 
solidarity of interests" could be the solution to the problems of a capitalist world. Her idea of communism, i.e. "free communism," relates to the non-existence of a state or party that determined people's lives. This idea was even strengthened by her Russian experiences, due to which she learned how a communist state could corrupt the ides of communism and freedom at the same time. It is also no wonder that Goldman disagreed with the course of the Russian Revolution from October 1917, considering that she had already declared in 1908 that

I believe government, organised authority, or the State is necessary only to maintain or protect property and monopoly. It has proven efficient in that function only. ... I therefore believe, with my fellow Anarchists, that the statutory regulations, legislative enactments, constitutional provisions, are invasive. They never yet induced man to do anything he could and would not do by virtue of his intellect or temperament, nor prevented anything that man was impelled to do by the same dictates. ... I believe-indeed, I know-that whatever is fine and beautiful in the human expresses and asserts itself in spite of government, and not because of it.

A free development, an unhindered advance of humanity, could consequently only exist if a state or government did not. Anarchism, the absence of government, needed to be achieved first, as it would then be able to "ensure the widest and greatest scope for unhampered human development, the cornerstone of true social progress and harmony."

However, it was not only the government that Goldman identified as an antipode of anarchism. Anarchists were "the only true advocates of peace, the only people who call a halt to the growing tendency of militarism, which is fast making of this erstwhile free country an imperialistic and despotic power," and this would lead to conflict with a government that was willing to act along militaristic lines. The conflict that would later be responsible for Goldman's deportation was actually one that was based on her criticism of the economy of war, which she and Berkman had identified, criticized, and began to explicitly address in public. Six years before the war in Europe began, Goldman had clearly attacked those who were in favor of war to prove national greatness:

The military spirit is the most merciless, heartless and brutal in existence. It fosters an institution for which there is not even a pretense of justification. The soldier, to quote Tolstoi, is a professional man-killer. He does not kill for the love of it, like a savage, or in a passion, like a homicide. He is a cold-blooded, mechanical, obedient tool of his military superiors. He is ready to cut throats or scuttle a ship at the command of his ranking officer, without knowing or, perhaps, caring how, why or wherefore. ... I believe that militarism will cease when the liberty-loving spirits of the world say to their masters: "Go and do your own killing. We have sacrificed ourselves and our loved ones long enough fighting your battles. In return you have made parasites and criminals of us in times of peace and brutalized us in times of war. You have separated us from our brothers and have made of the world a human 
slaughterhouse. No, we will not do your killing or fight for the country that you have stolen from us."

As a lecturer, Goldman also needed to be able to address people and to make them aware of the things she criticized with regard to the current state of American society or of the world at large. She consequently also emphasized the importance of free speech and a free press. It is almost ironic that these were two things the authorities would take away from her first in 1917 before they went to take away her right to live in the United States.

Next to the state, Goldman also criticized the church, which, as "an organized institution ... has always been a stumbling block to progress," and which "has turned religion into a nightmare that oppresses the human soul and holds the mind in bondage." One's actual life would be held in bondage by marriage, which Goldman considered from a female perspective to be "the life of a parasite, a dependent, helpless servant, while it furnishes the man the right of a chattel mortgage over a human life." anarchist eventually also discussed the role of violence. She begins by highlighting that anarchism per se was everything but violent: "I believe that Anarchism is the only philosophy of peace, the only theory of the social relationship that values human life above everything else. I know that some Anarchists have committed acts of violence, but it is the terrible economic inequality and great political injustice that prompt such acts, not Anarchism."77 The anarchist assassins were, in addition, not acting for personal gain, but represented with their actions "a conscious protest against some repressive, arbitrary, tyrannical measure from above." For Goldman, it was not the supposedly violent nature of anarchism or of those like Berkman who had tried to assassinate a representative of the ruling class, but rather "the unbearable economic and political pressure, the suffering and despair of their fellow men, women and children prompted the acts, and not the philosophy of Anarchism." Furthermore, the famous anarchist did not believe in such acts but in revolution by the people, as "the most powerful weapon, is the conscious, intelligent, organized, economic protest of the masses through direct action and the general strike." ${ }^{18}$ Goldman also contradicted the assump-

76 Goldman's view on marriage will be discussed in some more detail later. See the part on her feminist identity in the present chapter.

77 My emphasis.

78 The American socialist Daniel DeLeon (1852-1914) wrote important texts on the general strike as a political weapon, and Goldman seems to have been familiar with these writings as well. Daniel DeLeon, “What Means This Strike?” (1898). Accessed September 1, 2020. https:// www.marxists.org/archive/deleon/works/1898/980211.htm. For a study of his life and work, see 
tion that anarchist ideas would only lead to chaos. In contrast to many common beliefs, she highlighted that anarchism was oriented towards order, although a different kind of it:

The general contention that Anarchists are opposed to organization, and hence stand for chaos, is absolutely groundless. True, we do not believe in the compulsory, arbitrary side of organization that would compel people of antagonistic tastes and interests into a body and hold them there by coercion. Organization as the result of natural blending of common interests, brought about through voluntary adhesion, Anarchists do not only not oppose, but believe in as the only possible basis of social life. ... Indeed, only Anarchism makes non-authoritarian organization a reality, since it abolishes the existing antagonism between individuals and classes.

In particular, since anarchists were also longing for a classless society, they were willing to support the Russian Revolution in later years, and Goldman was no exception. Her dream was the achievement of a better world, which, for her, like for many others, was based on the idea of the abolition of social classes. Regardless of her political ideas, which would be congruent with many other anarchists, her identity as a woman is also important, since, as Donna M. Kowal correctly highlights, "Goldman's approach to anarchism emphasised the economic and psychosocial necessity of emancipating women, which she believed could only be accomplished through anarchism's ability to transcend artificial differences and class divisions between women and men." ${ }^{79}$ It is consequently necessary to look at another identity of Emma Goldman here as well, namely her anarchafeminist one. ${ }^{80}$

\section{The Anarcha-Feminist}

When the "priestess of anarchy," as Goldman was called by a reporter, was asked by the latter what anarchism could promise to women, she made it plain and simple: "More to woman than to anyone else-everything which she has not-

L. Glen Seretan, Daniel DeLeon: The Odyssey of an American Marxist (Cambridge, MA: Harvard University Press, 1979).

79 Kowal, “Anarcha-Feminism," 274.

80 Kowal defined anarcha-feminism, a label that did not yet exist in Goldman's own times, as "a distinct, albeit loosely formed, 'school of thought' that was reflected in the transnational activism of anarchist women, especially in Europe and the United States. Anarchist women tended to interpret the anarchist critique of authority through the lens of their experiences as women, especially constraints resulting from sexual double standards and the gendered division of labor.” Ibid., 265. 
freedom and equality." ${ }^{81}$ As mentioned before, it was hardly surprising that Goldman was revered by the feminist movement in the United States, especially since the famous anarchist had "argued that free love and access to birth control were necessary to empower women to live productive, creative, and healthy lives." 82 Goldman, who had worked as a nurse in the poorer parts of New York City during her first years as a lecturer, could refer to actual problems, especially the ones of women. ${ }^{83}$ Like many other anarcha-feminists, Goldman linked anarchist theories to these problems and argued on behalf of "an alternative model of womanhood." 84 Combining anarchist and feminist ideas, anarcha-feminists provoked criticism from male anarchists, who obviously had an anti-authoritarian idea of anarchism but would not argue on behalf of women's liberation, ${ }^{85}$ something that can be observed in early representatives of socialism or social democracy in different national contexts as well. ${ }^{86}$ Although united by their criticism of female suppression, there were different ideas or forms of anarcha-feminism, and with regard to their personal experiences, arguments, and methods, these women were quite different. ${ }^{87}$ Yet they all, in their own ways, criticized the gender and sexuality norms as they existed in around 1900 in the United States, as well as other countries.

In the case of the theoretical base of the female activists, including Goldman, “anarchism's anti-authoritarian and autonomous ethos ought to, and often has, extended to gender hierarchy and domination and sexual normativity, considering how freedom is restricted by these phenomena." 88 British gender and sexuality scholar Lucy Nicholas further highlights this anarchist dichotomy between public and private space when she writes that "[t]here was support for decentralisation of state power, but reification of essential, that is naturalised and therefore inevitable, gendered power within the family structure, reifying

81 Goldman, "What Is There in Anarchy for Woman?," 289.

82 Kowal, "Anarcha-Feminism," 274.

83 Solomon, Emma Goldman, 16-19.

84 Kowal, “Anarcha-Feminism," 266.

85 Lucy Nicholas, "Gender and Sexuality," in The Palgrave Handbook of Anarchism, ed. Carl Levy and Matthew S. Adams (Cham: Palgrave Macmillan, 2019), 605.

86 For Germany and the US respectively, see Vincent Streichhahn, "Zur 'Frauenfrage' und Sozialdemokratie im deutschen Kaiserreich: Zwischen Antifeminismus und Emanzipation” and Jowan A. Mohammed, "Mary Hunter Austin und die Forderungen nach einer Veränderung der Geschlechterrollen in den USA, 1914-1918," both forthcoming in Geschlecht und Klassenkampf: Die "Frauenfrage" aus deutscher und internationaler Perspektive im 19. und 20. Jahrhundert, eds. Vincent Streichhahn and Frank Jacob (Berlin: Metropol, 2020).

87 Kowal, “Anarcha-Feminism," 267, 275.

88 Nicholas, "Gender and Sexuality," 603. 
the public/private divide that so many feminist thinkers have identified as a key mode through which women's experience has been depoliticised and non-public domination ignored." ${ }^{89}$ The consequence was a rejection of hierarchy in any form, and anarchists like Goldman not only demanded the end of marriage as it existed but also full sexual freedom for all. They demanded freedom for women in every sense of the word and thereby challenged not only the state but also existent social and family structures. This made them appear radical among their male comrades as well and, at the same time, made them very attractive for the feminists of later generations. ${ }^{90}$

Goldman therefore particularly criticized the "feminization of poverty" 91 and demanded full self-control, including birth control, for women, whom she not only considered victims of capitalist exploitation by the upper classes but also victims of their own families. Together with other female anarchists like Voltairine de Cleyre (1866-1912), ${ }^{92}$ she argued that true freedom could be achieved if it existed for women and men alike. Some of the female anarchists considered monogamy as a form of suppression as well and demanded sexual freedom, something that probably went too far for many of their male comrades, who were not as radical as these women after all. ${ }^{93}$ Goldman was all in for change, and she traveled across the country and gave lectures on topics like "Birth Control" or "The Right of the Child Not To Be Born." In many regions of the US, this was thought of as rather scandalous, and Goldman, the well-known radical anarchist woman, was not considered a welcome guest by all men and women of the cities she planned to lecture in..$^{94}$

89 Ibid., 605.

90 Kowal, “Anarcha-Feminism,” 275-276.

91 Lori Marso, “The Perversions of Bored Liberals: Response to Herzog,” Political Theory 36, no. 1 (2008): 127.

92 On her life and work, as well as some selected writings, see Eugenia C. DeLamotte, Gates of Freedom: Voltairine de Cleyre and the Revolution of the Mind (Ann Arbor, MI: University of Michigan Press, 2004). Goldman also wrote a text she probably used for lectures about de Cleyre in later years. See Emma Goldman, "Voltairine de Cleyre," n.d., EGP-IISH, no. 271. The two anarchists were, however, often not very fond of each other, to say the least. De Cleyre, for example, complained about Goldman's lectures for women of the upper (middle) class. See Voltairine de Cleyre to Saul Yanovsky, October 18, 1910, Joseph Ishill Papers, Houghton Library, Harvard University; Voltairine de Cleyre to Joseph Cohen, October 26, 1910, 1, Joseph Cohen Papers, Bund Archives of the Jewish Labor Movement, YIVO Archives, New York. Both cited in McKinley, “The Quagmires of Necessity," 519.

93 Nicholas, "Gender and Sexuality," 610-611.

94 Marriner, "The Feminist Revolt," 130. 
With regard to her anarcha-feminism, Goldman borrowed thoughts and ideas from an even older generation of feminists, such as when she lectured about "Mary Wollstonecraft, the Pioneer of Modern Womanhood" in 1911. ${ }^{95}$ Alice Wexler, who edited and commented on this important lecture on the English philosopher and women's rights activist Mary Wollstonecraft (1759-1797), ${ }^{96}$ argues that "Goldman's portrait of Wollstonecraft is significant as the most revealing short self-portrait she ever wrote.” As Wexler continues her evaluation, she points out that the lecture shows many things that are typical of the famous female anarchist, as "Goldman expressed some of her most characteristic and contradictory attitudes: a blend of idealism and elitism; equal respect for intellect and for passion; deep concern for the welfare of the masses, but contempt for 'the mass' and 'the majority'; commitment to freedom, but a tendency to appeal to 'fate'; scorn for wealth and power, but an admiration for heroes." 97 The lecture provides a glimpse of greatness. Goldman would not only argue for Wollstonecraft due to her past activism but also claim the same for herself, although I disagree with Wexler's assessment that “Goldman's anarchism was founded less on an identification with the masses than on a sense of identity with the great rebels and martyrs of the past." 98 of course, Goldman liked herself a lot and her rather uncritical autobiography shows that quite clearly, but as a revolutionary anarchist, Goldman was not one of those who demanded leadership for the masses, as that in itself would be against her anarchist ideas, which have been lined out above. With regard to her hope for revolution in particular, Goldman needed the masses, and she knew that. That she was flattered by the success of her lectures on great figures of the past at the same time, and the applause and financial appreciation she received in return from her sometimes upperclass audiences, is not enough to claim that Goldman's whole vision of anarchism would have been self-centered. And, as this present chapter tries to highlight, Goldman had many different identities that overlapped, although one of them might have dominated from time to time.

Nevertheless, some elements of Goldman's lecture about Wollstonecraft could definitely be autobiographical reflections as well, such as when she says that

95 Emma Goldman, “On Mary Wollstonecraft," ed. and intro. Alice Wexler, Feminist Studies 7, no. 1 (1981): 114-121.

96 On her life and impact see, among others, Janet Todd, Mary Wollstonecraft: A Revolutionary Life (London: Weidenfeld \& Nicolson, 2000).

97 Goldman, “On Mary Wollstonecraft,” 113.

98 Ibid. 


\begin{abstract}
"Mary Wollstonecraft came into the World at a time when her sex was in chattel slavery: owned by the father while at home and passed on as a commodity to her husband when married. ... The family soon found itself in dire want, but how were middle-class girls to earn their own living with every avenue closed to them? They had but one calling, that was marriage. ... Her intellect saw the degradation of her sex, and her soul-always at white heat against every wrong-rebelled against the slavery of half of the human race. She determined to stand on her own feet." 99
\end{abstract}

The visionary women's rights activist was, in the lecture's representation, consequently not only a "pioneer of modern womanhood” but, like Goldman herself, also a "tragic romantic heroine."100 These two often contradictory and conflicting images also seem to run through Goldman's personal life, as she often struggled to live the ideals she demanded of herself and of society. Too often, Goldman seemed to lose her ideals in personal love relationships, a fact for which she probably criticized herself the most. It is, however, dangerous to explain all political ideas and thoughts that Goldman brought to paper in one way or another just by the emotional level of the author at the time the text was written. The personal level was only one important level for Goldman's views, and in her anarcha-feminist writings it was maybe one of the more decisive ones. If, however, we take a closer look at her theoretical works of anarchism, revolution, etc., it would underemphasize Goldman's intellectual capacity to explain her views solely as personal and emotional reactions.

Other authors, such as Candace Falk, have also remarked that “Goldman's reticence to qualify her personal and sexual radicalism reflected a strategic choice to avoid discrediting her ideas with 'her own personal failure to live out her vision of an open relationship." ${ }^{101}$ In particular, her relationship with her manager Ben Reitman (1879-1942) ${ }^{102}$ between 1908 and 1918, which Falk assessed as "probably the central sexual relationship in her life, tested her selfconfidence and tempted her to abandon her political work."103 Reitman exploited Goldman's popularity and tended to spend money on luxurious hotels during her lecture tours, something the latter was criticized for by other anarchists. Due to her love for her manager, however, Goldman tended to look the other way and

99 Ibid., 115.

100 Ibid., 125.

101 Ferguson, "Gender and Genre," 734. Ferguson refers to Falk, Love, Anarchy, and Emma Goldman, 155 in her text.

102 On Reitman's life and work, see Roger A. Bruns, The Damndest Radical: The Life and World of Ben Reitman, Chicago's Celebrated Social Reformer, Hobo King, and Whorehouse Physician (Urbana, IL: University of Illinois Press, 1986).

103 Falk, "Introduction," viii. 
let Reitman continue his spending out of her pocket. She had, in this context, not lived up to the radical ideals she publicly claimed necessary to change society as a whole, and thereby opened up many possibilities for her critics to attack her as a hypocrite. ${ }^{104}$ Yet Goldman herself describes the struggle between emotion and reason that befell her with regard to Reitman in Living My Life:

I again found letters from Ben beseeching me to let him come. I struggled against it for a time, but in the end a strange dream decided the issue. I dreamed that Ben was bending over me, his face close to mine, his hands on my chest. Flames were shooting from his finger-tips and slowly enveloping my body. I made no attempt to escape them. I strained towards them, craving to be consumed by their fire. When I awoke, my heart kept whispering to my rebellious brain that a great passion often inspired high thoughts and fine deeds. ${ }^{105}$

The other anarchists surrounding Goldman, including Berkman, were critical of Reitman, who did not seem to be interested in anarchist ideals but rather in the successful woman he could probably control. However, Goldman pushed such thoughts away and let her desires gain the upper hand: "He was from another world; moreover, he was impetuous and not always tactful. Clashes would surely follow, and I already had had to face far too many. I found it difficult to decide, but my need of Ben, of what his primitive nature could yield, was compelling. I resolved to have him; let the rest take care of itself." ${ }^{106}$ This should not be read as an accusation, especially since radicals like Goldman were only human, after all, and also have the right to get involved in toxic relationships.

Hence, Reitman, who exploited Goldman in many ways and would eventually turn against her, as will be shown later, also suffered due to his relationship with her and his role as her manager, especially from anti-Goldman and anti-anarchist violence when he visited San Diego during the Free Speech Fight in 1912:

Dr. Ben Reitman, a big, husky fellow, the manager of Goldman, came to San Diego to help in the free speech fight. On the evening of his arrival, the vigilantees kidnapped him from his hotel room and drove him out in a car followed by other vigilantees to a deserted hideaway. They beat him up, undressed him, poured tar on his naked body. With a lighted cigar, they burned the letters I.W.W. on his body, then rubbed sagebrush on him. They knocked him out, twisted his testicles, forced him to kiss the American flag and sing the "Star Spangled Banner." After that, the vigilantees lined up and made him run the gauntlet, each of them giving him a blow or a kick. In this condition, he was left in the field. ${ }^{107}$

104 Ferguson, "Gender and Genre," 734-735.

105 Goldman, Living My Life, ch. 32.

106 Ibid., ch. 33.

107 Wisotsky Autobiographical Typescript, 83-84. Also see: Goldman, Living My Life, ch. 38. On the San Diego Free Speech Fight, see Grace L. Miller, “The I.W.W. Free Speech Fight: San 
For her critics, nevertheless, Goldman's emotional engagement and dependency were displayed as weaknesses, as the famous anarchist obviously was not managing to live up to the ideals she always claimed to be necessary to achieve total equality and the freedom of women within American society. ${ }^{108}$ In a letter to Berkman that Goldman wrote on 4 September 1925, the latter explained this dilemma in retrospect:

The tragedy of all of us modern women ... is a fact that we are removed only by a very short period from our traditions, the traditions of being loved, cared for, protected, secured, and above all, the time when women could look forward to an old age of children, a home and someone to brighten their lives. ... The modern woman cannot be the wife and mother in the old sense, and the new medium has not yet been devised, I mean the way of being wife, mother, friend and yet retain one's complete freedom. Will it ever? ${ }^{109}$

Regardless of Goldman's failure to achieve a true change of the female role in her own relationship, the famous anarchist continued to demand such a change, which would have to be based on sexual freedom as well. As feminist scholar Clare Hemmings pointed out, “Goldman's centring of sexual freedom at the heart of revolutionary vision and practice is part of a long tradition of sexual politics, one that struggles to make sense of how productive and reproductive labour come together, and to identify the difference between sexual freedom and capitalist opportunity." 110 There is no doubt that Goldman shocked many of her contemporaries with her views on sexual freedom, but she also must have felt the pressure in her personal relationships to bend her strong convictions if she was interested in experiencing a contemporary and actual but not utopian relationship, and Goldman must have been disappointed about that. Her time was obviously not ready for women who would freely and openly express their desires as well as their thoughts about sexual pleasure. ${ }^{111}$

Diego, 1912,” Southem California Quarterly 54, no. 3 (1972): 211-238; Rosalie Shanks, “The I.W.W. Free Speech Movement: San Diego, 1912,” Journal of San Diego History 19, no.1 (1973): 25-33. For a list of IWW activities and strikes in 1912, see Michael Hanley, "IWW Yearbook 1912," IWW History Project. Accessed September 1, 2020. https://depts.washington.edu/iww/yearbook1912. shtml.

108 Ferguson, "Gender and Genre," 735.

109 Letter to Alexander Berkman, September 4, 1925, in Nowhere at Home: Letters from Exile of Emma Goldman and Alexander Berkman, ed. Richard Drinnon and Anna Maria Drinnon (New York: Schocker, 1975), 131-133, cited in Ferguson, “Gender and Genre,” 736.

110 Clare Hemmings, "Sexual Freedom and the Promise of Revolution: Emma Goldman's Passion,” Feminist Review 106 (2014): 44.

111 Ibid., 45-46. 
For Goldman, these freedoms were essential necessities for a change of society and an end of the exploitation of women, whose status of exploited labor force was intensified by the exploitation they experienced as wives and mothers. ${ }^{112}$ Goldman also warned the suffragists that suffrage alone would not change the situation in which many women suffered, and she highlighted that the political change needed to be accompanied by a social change as well, especially since "the achievement of suffrage would [only] lead to a strengthening of the state in its role in structuring and legally enforcing class oppression."113 Eventually, the granting of the right to vote would change little with regard to the suppressive environment for women, and it took many more years before the voices that demanded true equality were heard, although this equality has still not been achieved yet. ${ }^{114}$ Considering this, Goldman's voice is even more important, as, quite early on, she criticized what Hemmings called "the twin fantasies of protection and social mobility through marriage." 115 For Goldman, marriage represented the misery of all women, as it only offered "sorrow, misery, [and] humiliation"116 and would represent the private side of women's exploitation by a capitalist society. Women were, as Goldman's argument continued, considered a private commodity that could be sexually exploited by the husband, and their workforce was not only exploited in the American capitalist system, which was based on the sheer number of female workers, but also within their families, a space where women had to work numerous unpaid hours, often left alone by their husbands. Marriage was consequently often nothing more than "an economic arrangement, an insurance pact." ${ }^{117}$ Being married would create dependencies for women they could never escape from, as, once married, "women have nowhere to go, are trapped in their dependency, parasitism and pettiness, and cling desperately to the scant rewards of corruption."118 Like men, according to Goldman's view, women “groan under the iron yoke of our marriage institu-

112 Emma Goldman, “The Tragedy of Women's Emancipation,” Mother Earth 1, no. 1 (1906): 9-18.

113 Christine Cricket Keating, “Toward an Emancipatory Citizenship,” Women's Studies Quarterly 43, no. 3/4 (2015): 295.

114 Marriner, "The Feminist Revolt," 132.

115 Clare Hemmings, "In the Mood for Revolution: Emma Goldman's Passion,” New Literary History 43, no. 3 (2012): 527.

116 Emma Goldman, “Marriage," Firebrand, July 18, 1897: 2, in Emma Goldman: A Documentary History of the American Years, vol. 1: Made for America, 1890-1901, ed. Candace Falk et al. (Urbana, IL: University of Illinois Press, 2008), 269-273.

117 Emma Goldman, Marriage and Love (New York: Mother Earth, 1911), 4, cited in Hemmings, "Sexual Freedom," 49.

118 Hemmings, "Sexual Freedom," 50. 
tion, and there seems to be no relief, no way out of it." Social change needed to end this institution, because "marriage relations, are the foundation of private property, ergo, the foundation of our cruel and inhuman system." Marriage would establish total male control over women, "not only over her body, but also over her actions, her wishes; in fact, over her whole life." Society consequently had to overcome the traditional role models and abolish them, and at the same time abolish the institutionalization of these role models, i.e. marriage, because

the boy is taught to be intelligent, bright, clever, strong, athletic, independent and selfreliant; to develop his natural faculties, to follow his passions and desires. The girl has been taught to dress, to stand before the looking glass and admire herself, to control her emotions, her passions, her wishes, to hide her mental defects and to combine what little intelligence and ability she has on one point, and that is, the quickest and best way to angle a husband, to get profitably married. ${ }^{119}$

Marriage is consequently detached from emotions like love, as the institution of marriage is considered as an insurance policy for the exploited class, albeit only for the men of this class:

Both, the man and the girl, marry for the same purpose, with the only exception that the man is not expected to give up his individuality, his name, his independence, whereas the girl has to sell herself, body and soul, for the pleasure of being someone's wife; hence they do not stand on equal terms, and where there is no equality there can be no harmony. The consequence is that shortly after the first few months, or to make all allowance possible, after the first year, both come to the conclusion that marriage is a failure. ${ }^{120}$

The woman is ultimately nothing more than "the slave of her husband and her children" and is exploited day by day, as "[s]he should take her part in the business world the same as the man" as well but is paid less in comparison, since she is not paid at all for her work at home: "The woman, instead of being the household queen, told about in story books, is the servant, the mistress, and the slave of both husband and children. She loses her own individuality entirely, even her name she is not allowed to keep." ${ }^{121}$ Goldman directed such criticism to her chauvinist anarchist comrades as well, and highlighted during her speeches that "[w]oman cannot without equal opportunity ever rise to equality with him

119 Goldman, “Marriage,” 269.

120 Ibid., 271.

121 Goldman, "What Is There in Anarchy for Woman?” 291. 
[man], and hence women are slaves to society as a consequence, and intensified under the marriage code." ${ }^{122}$

Goldman could observe that her remarks and critical demands changed little. Suffrage was granted to women in the US after the First World War, but true equality was not really achieved. During her lectures in the later years of her career, Goldman would consequently talk about the "Tragedy of the Modern Woman." 123 In retrospect, she argued that "[w]oman's rights sponsors faithfully promised that woman's political and economic equality with man would abolish war, prostitution, crime and all other evils in the world," but the reality proved "that woman in politics is by no means better than man and her right of suffrage has helped her as little as it did most men to overcome outworn political, social, or moral values." ${ }^{\prime 24}$ Women, unfortunately, as Goldman continues her assessment, have "to a large extent remained fettered by her tradition." 125 She might have also critically reflected on her own faults in her romantic relationships, such as with Reitman, when she later declares that when the modern woman "loves the man, she turns him into a god and surrounds him with a sacred hallow. In her blind idolization she fails to see that her deity is but human, all too human. The poor fool knows only too well that he is far from the hero imagined by his mother, wife, daughter, or mistress." ${ }^{126}$ At the same time, although "[e]mancipation has brought woman economic equality with man," female labor was not considered to be equally valuable, and women "are neither met with the same confidence as their male colleagues, nor receive equal remuneration." ${ }^{127}$ Due to this inequality, many girls and young women still dream of escaping labor exploitation through marriage. With regard to this continuing trend, which Goldman had criticized multiple times in the past, she again asks in her reflection: "As to the great mass of working girls and women, how much independence is gained if the narrowness and lack of freedom of the home is exchanged for the narrowness and lack of freedom of the factory, sweat-shop, department store, or office?" ${ }^{128}$ Being free but exploited seems still less attractive than being enslaved and solely exploited by a husband. Con-

122 Emma Goldman, “The New Woman,” Free Society, February 13, 1898: 2, in Emma Goldman: A Documentary History of the American Years, vol. 1: Made for America, 1890-1901, ed. Candace Falk et al. (Urbana, IL: University of Illinois Press, 2008), 322.

123 Emma Goldman, “The Tragedy of the Modern Woman,” n.d., EGP-IISH, no. 266.

124 Ibid., 1.

125 Ibid., 1-2.

126 Ibid., 3.

127 Ibid., 12.

128 Ibid., $13^{1 / 2}$. 
sequently, women are not really free, and the "highly praised independence is, after all, but a slow process of dulling and stifling woman's nature, her low need, and her mother instinct." ${ }^{129}$ True freedom is consequently often sacrificed to match the expectations of a society that was in a way based on these exploitative methods. And the movements that fought against women's exploitation? Goldman criticized the halfheartedness of many representatives of these movements when she argued that "[e]very movement that aims at the destruction of existing institutions and the replacement thereof with something more advanced, more perfect had followers who in theory stand for the most radical ideas, but who, nevertheless, in their every-day practice, are like the average philistine, feigning respectability and clamoring for the good opinion of their opponents. The suffragist and feminist movements made no exception." 130 The tragedy of the modern woman, however, is very much related to the unwillingness of the modern man to let her be truly free. The latter "still wants woman as his housekeeper and caretaker of his home and his children," "131 and the modern woman "lacks [the] courage to be inwardly free. Even with herself she is not frank." 132 She is held back by "sentimental considerations" and "still has too many gods," 133 and "foolish women pave the way for men's career as they deny themselves while supporting the man."134 This was supposed to be a consequence of the fact that "woman has not yet learned to march to victory regardless of the defeat of those in her way. Hence she has not reached greatness."135 The self-sacrifice of women for their families and husbands, who obviously did not appreciate such a sacrifice enough, meant that the development of the modern woman was sabotaged and freedom, in every sense of the word, consequently seemed to be far away. At the same time, those women, probably including Goldman herself, who had advanced and achieved something were less attractive to men, because "the higher the mental development of woman, the less possible it is for her to meet a congenial mate who will see in her, not only sex, but also the human being, the friend, the comrade and strong individuality, who cannot and ought not lose a single trait of her character." ${ }^{136}$ In addition, the existent form of institutionalized relationships, i.e. marriage, is not based on

\footnotetext{
129 Ibid., 14.

130 Ibid., $18^{1 / 2}$.

131 Ibid., 22.

132 Ibid., 29.

133 Ibid., 30.

134 Ibid., 30 - 31.

135 Ibid., 31.

136 Ibid., 33.
} 
love and therefore most perceptions of marriage are wrong because, as Goldman argued, "it is not love, but a transaction that never fails to lay stress on a plus and a minus."137 The famous anarchist therefore concluded that woman needed to achieve true emancipation and claimed that "her freedom will reach as far as her love for it and her will to achieve her freedom."138 Only if women accepted the reality, i.e. that they were suppressed, and demanded an uncontested freedom for themselves could they become emancipated. To achieve a successful emancipation, however, the modern woman would "have to do away with the absurd notion of the conflict of the sexes, or that man and woman represent two antagonistic worlds," although "in a social sense woman will only become truly free when man will become free. There is no merit in being the equal of slaves in a slave society." 139 To achieve such freedom, the modern woman would also have to fight for her sexual liberation.

Goldman, who had been in contact with famous thinkers and advocates for the freedom and liberation of human sexuality, such as Magnus Hirschfeld (1868-1935), ${ }^{140}$ also lectured on "The Element of Sex in Life," ${ }^{141}$ highlighting the role of unexcused sexual pleasure. Goldman argued in this text that "[i]t is ... indispensable to recognize this much-maligned sex impulse as the great psychological motive force of humanity." ${ }^{42}$ Sex, she said, in a way self-critically, "is woven into every fabric of human life and lays its finger on every custom. To the debit side of the sex account we must charge many silly stupidities and some of the foulest injustices which go to make the thing we call human culture the amazing and variegated mosaic that it is." 143 At the same time, it can liberate the female sex, although society considers it "disgraceful for nice girls." 144 However, the sex taboo, as it existed in modern societies, especially for women, also prevented happy relationships, as "[m]ost men are brought up to believe that woman must be taken and not give herself gladly and joyously in love and passion.” ${ }^{245}$ Furthermore, the sex taboos of Goldman's time prevented married peo-

137 Ibid., $36^{1 / 2}$

138 Ibid., 40.

139 Ibid., 41.

140 Magnus Hirschfeld to Emma Goldman, Paris, November 24, 1933, EGP-IISH, no. 98. On Hirschfeld's life and work, see Manfred Herzer, Magnus Hirschfeld und seine Zeit (Berlin: De Gruyter, 2017).

141 Emma Goldman, “The Element of Sex in Life,” n.d., EGP-IISH, no. 213.

142 Ibid., 5.

143 Ibid., 7-8.

144 Ibid., 21.

145 Ibid., 24. 
ple from actually addressing their sexual needs, further sabotaging a form of relationship that consequently could never be based on true love and emotion:

Take frigidity in some women largely due to the deadening effect of the sex taboo. Such women cannot even if they try desperately respond to the sex urge in the man. In fact, the very thought of the sexual embrace to such women is torture. Even if the man lacks refinement and imposes his needs on his wife he will find no satisfaction. In the end he seeks gratification elsewhere. There is quite a percentage of married men among the clientele of prostitution. Sex is more powerful than all decisions. The man will grow indifferent and in the end insist on divorce. ${ }^{146}$

True equality and its achievement therefore needed sexual liberation and the end of taboos that did not really help anybody. Goldman, with regard to this issue, almost naturally made the following demand: "Let us get rid of the mock modesty so prevalent on the surface of polite society, let us liberate sex from falsehood and degradation.”147

Even today, Goldman's demands seem to be utopian, as the tragedy for the modern woman she described continued and sexual liberation has not yet been fully achieved for all. And that despite Goldman's dream not really being extraordinary. As Kathy E. Ferguson described, Goldman "wanted a world without jealousy, insecurity, or possessiveness, and she fought those feelings in herself, with limited success." Her "elevated expectations for the transformative power of love is a mirror image of her intense desire for revolution as a transvaluation of values. Her passion for her individual lovers intertwined with her passion for radical political change." Nevertheless, and regardless of her personal emotional disappointments, Goldman never let frustration change her anarchist ideals, and for her "[t]he parallel between love and revolution in both her ideas and her actions holds a stronger promise for radical feminist interventions than do the inconsistencies between what she practiced and what she preached." 148

When discussing Goldman's anarcha-feminist views, it is also important that she highlighted not only the role of women for revolutionary success but also her considerations about female sexuality "within the means of production and the exploitation of surplus labour." ${ }^{149}$ She went beyond a purely economic perspective to identify the negative influence of capitalism for the exploited class, but incorporated social and sexual aspects into her anarchist narrative that would ultimately demand a revolution that was based on true freedom, i.e. a freedom

146 Ibid., 26-27.

147 Ibid., 50.

148 Ferguson, "Gender and Genre," 751.

149 Hemmings, "Sexual Freedom," 50. 
that would not only change the income of the workers but truly free every aspect of human life and the relationships the latter would be expressed by. Sexual freedom ${ }^{150}$ and birth control ${ }^{151}$ seemed to be necessary preconditions to actually better the lives of women, whose equality on paper might have been achieved by political changes like the granting of women's suffrage, but whose lives would never become better if these changes did not impact the social side of female life as well. Sexuality, according to Goldman, was an essential aspect of change and, as Clare Hemmings correctly emphasized, "a productive site of revolutionary transformation, as well as co-optation."152 This also means that Goldman never thought revolutionary processes to be solely political, but considered them as transformative in every sense of the word, especially with regard to the liberation of the modern woman. It was and still is important to understand, when one studies Goldman's anarcha-feminist texts today, that sexual freedom possesses a "methodological capacity to disrupt the unequal division of labour at the heart of re/production, since once women withdraw their reproductive, commercial and affective labour, the cogs of capitalism, militarism and religious ideology will grind to a halt." 153 To better understand the revolutionary Goldman, one consequently has to be aware that her "anarchist vision of a revolution" was fundamentally based on "women's sexual emancipation,"154 the latter consequently being one of the core elements, alongside freedom in the truest sense of the word, of her revolutionary considerations. How could a revolution succeed if the revolutionaries had no passion and love for it? Anecdotally speaking, Goldman was not interested in a revolution when she was not allowed to dance while changing the world:

At the dances I was one of the most untiring and gayest. One evening a cousin of Sasha, a young boy, took me aside. With a grave face, as if he were about to announce the death of a dear comrade, he whispered to me that it did not behoove an agitator to dance. Certainly not with such reckless abandon, anyway. It was undignified for one who was on the way to become a force in the anarchist movement. My frivolity would only hurt the Cause. I grew

150 Referring to the American poet Walt Whitman (1819-1892), Goldman praised "the beauty and wholesomeness of sex ... freed from the rags and tatters of hypocrisy." Emma Goldman, "Walt Whitman (1916)," in The Emma Goldman Papers: A Microfilm Edition, ed. Candace Falk with Ronald J. Zborayetal, reel 54 (Alexandria, VA: Chadwyck-Healey, 1990), 2, cited in Ferguson, "Gender and Genre," 747.

151 Emma Goldman, “The Social Aspects of Birth Control,” Mother Earth 11, no. 2 (1916): 468 475.

152 Hemmings, "Sexual Freedom," 51.

153 Ibid., 51-52.

154 Ibid., 56; see also 44. 
furious at the impudent interference of the boy. I told him to mind his own business, I was tired of having the Cause constantly thrown into my face. I did not believe that a Cause which stood for a beautiful ideal, for anarchism, for release and freedom from conventions and prejudice, should demand the denial of life and joy. I insisted that our Cause could not expect me to become a nun and that the movement should not be turned into a cloister. If it meant that, I did not want it. "I want freedom, the right to self-expression, everybody's right to beautiful, radiant things." Anarchism meant that to me, and I would live it in spite of the whole world-prisons, persecution, everything. Yes, even in spite of the condemnation of my own closest comrades I would live my beautiful ideal. ${ }^{155}$

Goldman therefore pays attention not only to gender roles and sexual freedom but also passion as an essential revolutionary force. She believed, like other anarchists, to quote Hemmings once more, "that revolution will be brought about through labour interventions (strikes, education of the masses), but also through individual and collective practices in everyday life that can inaugurate a different set of values, and from which the vision of a better world might arise." ${ }^{156}$ In contrast to her male comrades, however, Goldman was more sensitive to incorporating female perspectives into her idea for a revolution, which was naturally a "sexual and gendered revolution" that would focus on otherwise "lost voices." 157 To understand the revolutionary Goldman, one consequently has to understand the anarcha-feminist. However, Goldman was also a publicist for some years of her life, trying to actively participate in and influence anarchist debates about revolution and the future it was supposed to bring.

\section{The Publicist}

In contrast to Volrairine de Cleyre, who disliked her work as a teacher but never felt it to be convenient to live off the anarchist movement, Goldman, who had worked in the factories and as a nurse-she had even studied midwifery and nursing in Vienna in 1895/96-eventually tried to become a "professional anarchist" who could live off lectures and publications. When Goldman had a choice to continue nursing in the poor parts of New York City or to fully dedicate her energy to the anarchist cause, she chose the latter. At this point, it has to be emphasized that Goldman never became rich, and all the money she had she invested in the publication of anarchist ideas-not only her own but also those of oth-

155 Goldman, Living My Life, ch. 5.

156 Hemmings, "Sexual Freedom," 49.

157 Ibid. 
ers. She used her fame to leave part-time anarchism, which she practiced between 1892 and 1906, behind and founded Mother Earth, her own anarchist journal that would provide a melting pot for all kinds of ideas and thoughts related to anarchism. ${ }^{158}$ In 1905, however, Goldman had borrowed money from some friends and had initially opened a parlor for facial and scalp massages, which would serve the growing middle-class demand for such services. The business ran well and Goldman earned some money, continuing her anarchist work on the side. She could repay some of her debts and even made sufficient money to accumulate capital. When she had the opportunity to create Mother Earth, however, she left the opportunity to become rich as a business owner behind without hesitation. Goldman was a revolutionary mind, not a capitalist. ${ }^{159}$

For herself, the step to get active as a publicist ended her double life. From 1906 onwards, Goldman was a professional anarchist. And she used her position quite well to support Alexander Berkman too, who was released from prison in the same year and worked with Goldman on her monthly journal. She also continued to lecture, and although many anarchists would do that for free, the famous anarchist "regularly charged an admission in order to sustain not only Mother Earth, but also Goldman herself, her editor, Alexander Berkman, and, at least at times, her manager and lover, Ben Reitman."160 For such practices, she was criticized by other anarchists like de Cleyre, who argued that Goldman lived not for but rather off the anarchist movement. ${ }^{161}$ Although she never actually used large sums of the money she collected for her own luxury but instead helped many anarchists with her income, such accusations must have bothered Goldman. However, the income she generated was important, as she highlights in Living My Life about the time immediately after Mother Earth was launched: "My tours had become the main source of revenue for the magazine, for the publication of our literature and the other expenses involved."162

From a financial perspective, Goldman's lectures and works on drama and Russian literature were especially successful. ${ }^{163}$ She was also involved in theater performances in many parts of the United States and, as part of her idea that education would spread revolutionary consciousness, she lectured on the impor-

158 McKinley, “The Quagmires of Necessity,” 512, 516.

159 Ibid., 517.

160 Ibid.

161 Ibid., 519.

162 Goldman, Living My Life, ch. 33.

163 Emma Goldmann, The Social Significance of Modern Drama (Boston, MA: R.G. Badger, 1914). In particular, her lectures on Russian dramatists, such as Leo Tolstoy or Maxim Gorky, were quite successful. See Ferguson, “Gender and Genre,” 738. 
tance of theater for the masses, including the promotion of Yiddish playwrights, such as Sholem Asch (1880 - 1957), ${ }^{164}$ among American and later British audiences. ${ }^{165}$ Goldman considered Mother Earth to be more than just a political publication-she envisioned it as work that would provide a broad cultural discussion, and her own "celebration of freedom in the arts, politics, work, education, and sexual life were very much a part of the pre-World War I modernist rebellion of bohemians, radicals, and artists." 166 In the column "The Avant Garde," modernist ideas were presented to a wider public and stimulated discourses in many different fields. Although Kathy E. Ferguson argued that "for Goldman, as for others in her generation of radicals, modernism was not a primary source of her energies," 167 one has to highlight that Goldman's mind seemed quite open to new ideas, although she loved the Russian literary classics, and that she was open-minded enough to discuss her own mistakes, something that is especially visible with regard to her writings about the Russian Revolution.

In addition, Goldman often herself did differentiate between her anarchist ideas and her own preferences with regard to modern drama. The audiences for both were as different as they could be. As mentioned before, she also was aware that the latter would finance her and Berkman's publicist activities, whether this was Goldman's Mother Earth or other projects. ${ }^{168}$ Considering that many anarchists, however, were poor workers, there was almost no alternative to this practical method. Goldman, in a way, was relying on her attraction to the bourgeois middle class, whose representatives visited her lectures on drama, to pay for the publications that were supposed to awaken the working class. All in all, and like many other revolutionaries, Goldman realized that she needed to rely on capitalist means to work towards her revolutionary aims. She was consequently sometimes eager to make the most out of her lecture series financially. ${ }^{169}$ One could, however, also add that Goldman enjoyed the attention she received from well-situated middle-class women during her lectures.

164 On his life and work, see Joseph Sherman, “Asch, Sholem," The YIVO Encyclopedia of Jews in Eastern Europe. Accessed September 1, 2020. https://yivoencyclopedia.org/article.aspx/Asch_ Sholem.

165 Ferguson, “Gender and Genre,” 739.

166 Ibid., 743.

167 Ibid., 743-744. Ferguson later admits that "Goldman was quite modern in her political vision but not in her aesthetic practices. While she often made alliances with modernists, her head and her heart were grounded in romantic realism.” Ibid., 744.

168 McKinley, “The Quagmires of Necessity,” 518.

169 Emma Goldman to Ben Reitman, March 18 [no year] and December 18, 1909, Ben Reitman Papers, Manuscript Collection of the University of Illinois at Chicago Circle Library, cited in ibid. 
However, as mentioned before, this does not provide sufficient reason to condemn her activities as such. Again, it becomes clear that Emma Goldman had many different identities and was interested in many eclectic things at the same time, although she never lost her focus on a possible revolution in the future. In a way, Goldman was successful in re-exploiting the bourgeoisie to finance this revolution, or, as Blaine McKinley described it,

\begin{abstract}
Anarchists have often been viewed as hopelessly impractical dreamers. While certainly idealistic, the anarchists also had a pragmatic streak that enabled them to deal with capitalistic society, however much they despised it. Indeed, Emma Goldman's understanding of the promotional techniques required to market anarchism in a bourgeois society made her America's most successful anarchist agitator. Yet Goldman was more successful than most anarchists, or most American dissidents generally, in unifying her work with her life and with her goals. ${ }^{170}$
\end{abstract}

The financing of Mother Earth ${ }^{171}$ was actually one of these goals. According to Goldman's aims, "[t]he magazine was to be a forum for anarchism of every school and variety." ${ }^{172}$ Mother Earth was an important melting pot, a nodal point of the American anarchist movements and its different representatives, be they readers or writers, editors or printers, artists or other bohemians, etc. It provided a platform for different protest movements as well, no matter if they addressed or reacted to capitalist exploitation, imperialist wars, or the treatment of political prisoners. ${ }^{173}$ Mother Earth was published for 12 years, and during this time, "it was an essential part of the action"174 and a front for the US anarchist movement.

For Berkman, whom Goldman supported in many ways after his release from prison in 1906, the journal provided a possibility to return to the anarchist movement outside the prison walls and to become an active part of the movement again. After his 14 years behind bars, Goldman happily announced: "One buried alive for fourteen years will emerge from his tomb." 175 The cause of Berkman's and Goldman's activism had not changed, however, and so the former could simply join forces with the latter again to achieve the aim they had been fighting for

170 Ibid., 522.

171 On the history of Mother Earth, see Solomon, Emma Goldman, 21-23.

172 Glassgold, "Introduction,” xvii.

173 Kathy E. Ferguson, “Assemblages of Anarchists: Political Aesthetics in Mother Earth,” The Journal of Modern Periodical Studies 4, no. 2 (2014): 172.

174 Glassgold, "Introduction," xvii.

175 E.[mma] G.[oldman], “Alexander Berkman,” Mother Earth 1, no. 3 (1906): 22-24. Accessed September 1, 2020. http://www.gutenberg.org/files/27262/27262-h/27262-h.htm\#Page_22. 
since the early 1890s. With regard to this, the article in Mother Earth on Berkman's release from prison also declared:

\begin{abstract}
In looking over the events of 1892 and the causes that led up to the act of Alexander Berkman, one beholds Mammon seated upon a throne built of human bodies, without a trace of sympathy on its Gorgon brow for the creatures it controls. These victims, bent and worn, with the reflex of the glow of the steel and iron furnaces in their haggard faces, carry their sacrificial offerings to the ever-insatiable monster, capitalism. In its greed, however, it reaches out for more; it neither sees the gleam of hate in the sunken eyes of its slaves, nor can it hear the murmurs of discontent and rebellion coming forth from their heaving breasts. Yet, discontent continues until one day it raises its mighty voice and demands to be heard: Human conditions! higher pay! fewer hours in the inferno at Homestead, the stronghold of the "philanthropist" Carnegie! ${ }^{176}$
\end{abstract}

In contrast to the US steel tycoon, Berkman was really the one who cared for the well-being of the masses and was described by his former lover, Goldman, as “[a] youth with a vision of a grand and beautiful world based upon freedom and harmony, and with boundless sympathy for the suffering of the masses. One whose deep, sensitive nature could not endure the barbarisms of our times. Such was the personality of the man who staked his life as a protest against tyranny and iniquity." 177 Since nothing about these facts had changed, it seemed more than natural that the famous anarchist who had just been released from prison would continue his important work by supporting Goldman's newly established journal.

Berkman himself described the moment he left the prison as "a moment of supreme joy when I felt the heavy chains, that had bound me so long, give way with the final clang of the iron doors behind me and I suddenly found myself transported, as it were, from the dreary night of my prison-existence into the warm sunshine of the living day." ${ }^{178}$ Between 1906 and 1918, Mother Earth was published in New York City, bringing together many names of the anarchist movement there. Many of those involved also worked on other publications, e.g. The Blast or The Modern School. The subscriber list-around 2,000 individuals or organizations in total-of Mother Earth also mentioned other publications all around the globe, which is why the impact of the journal should not be underemphasized, although it was very often not financially self-supporting. ${ }^{179}$ The different readers of Mother Earth included "anarchists, feminists, trade union-

176 Ibid. Goldman here makes a reference to the steel tycoon Andrew Carnegie (1835-1919).

177 Ibid.

178 Berkman, "A Greeting."

179 Ferguson, “Assemblages of Anarchists,” 173-174. 
ists, civil libertarians, and progressives of various alignments, not to mention persistent eavesdroppers from various state surveillance agencies."180 Goldman, who had read and seen anarchist publications from different national contexts, followed the French magazine L'Humanite Nouvelle ${ }^{181}$ when she created her journal, and the issues of Mother Earth providea deep and detailed insight into anarchism and progressive political thought in early 20th century America. ${ }^{182}$

After six years of Mother Earth's existence and a lot of work invested in it by Emma Goldman and Alexander Berkman, they published an assessment, which shall be quoted here in some detail because it highlights that although Mother Earth was an important anarchist publication, the "success" story of the journal was quite ambivalent:

Viewed from the dominant standpoint of success ... Mother Earth has failed. Our circulation is still far from the fifty-thousand mark; our subscribers, too, do not represent the multitudes. Nor is our financial rating such that we need feel any anxiety lest a Wall Street panic break our bank. Again, Mother Earth has lost in averdupois; it began as a heavyweight of sixty-four pages, but is now reduced to the lightweight class. But since when do Anarchists measure success by quantity? Are numbers, weight, or following the true criterion of success? Should not the latter consist, first of all, in adherence to the chosen purpose, no matter at what cost? Indeed, the only success of any value has been the failure of men and women who struggled, suffered, and bled for an ideal, rather than give up, or be silenced. Mother EARTH is such a success. Without a party to back her, with little or no support from her own ranks, and consistently refusing to be gagged by a profitable advertising department, she has bravely weathered the strain of five years, stormy enough to have broken many a strong spirit. She has created an atmosphere for herself which few Anarchist publications in America have been able to equal. She has gathered around her a coterie of men and women who are among the best in the country, and, finally, she has acted as a leaven of thought in quarters least expected by those who are ready with advice, yet unable to help. ... As to the original raison d'etre of MOTHER EARTH, it was, first of all, to create a medium for the free expression of our ideas, a medium bold, defiant, and unafraid. That she has proved to the fullest, for neither friend nor foe has been able to gag her. Secondly, MOTHER EARTH was to serve as a gathering point, as it were, for those, who, struggling to free themselves from the absurdities of the Old, had not yet reached firm footing. Suspended between heaven and hell, they have found in MOTHER EARTH the anchor of life. Thirdly, to infuse new blood into Anarchism, which - in America - had then been run-

180 Ibid., 174.

181 L'Humanite Nouvelle: The Revue Internationale-Sciences, Lettres Et Arts was published in France between 1897 and 1903 by the French socialist-anarchist Augustin Hamon (18621945). His other works include Psychologie de l'anarchiste-socialiste (Paris: Stock, 1895).

182 For a detailed discussion, see Craig Monk, "Emma Goldman, Mother Earth, and the Little Magazine Impulse in Modern America," in "The Only Efficient Instrument": American Women Writers and the Periodical, 1837-1916, ed. Aleta Fainsod Cane and Susan Alves (Iowa City: University of Iowa Press, 2001), 113-125. 
ning at low ebb for quite some time. All these purposes, it may be said impartially, the magazine has served faithfully and well. ${ }^{183}$

It is almost ironic from an anarchist perspective that Goldman had invested all her energy in a project that would eventually be "killed by the wartime postal censorship"184 during the First World War in August 1917. The Mother Earth Bulletin, which replaced Mother Earth, eventually ceased being published in April 1918. Due to Goldman's and Berkman's criticism of the US government during the war, they had become a target of anti-anarchist suppression and, once deported, they could not continue their own publication activities in the United States. The forced end of her identity as an anarchist publicist would then, however, turn Goldman into a full revolutionary, although her hopes that she had tied to the Russian Revolution and the Bolsheviki would be so tremendously disappointed shortly after. Goldman, nevertheless, had already been a revolutionary before 1917.

\section{The Revolutionary}

Emma Goldman was a passionate revolutionary who hoped that the spark of revolution would set the masses on fire and lead to a movement that would wash away all the capitalist perversions US society was suffering from. She combined anarchist theory, feminist necessities, and publicist means to achieve this goal, yet she seemed to have been unable to really challenge the state and its government, as the authorities hit back quite hard and determinedly pushed Goldman out of their way. She was the most notorious and probably one of the best-known anarchists in the world. That the US authorities joined the global anarchist craze in the early 1900s after McKinley's assassination even increased Goldman's global fame. ${ }^{185}$ Using her famous position, Goldman not only tried to form a strong anarchist movement that would prepare the revolution in the United States,

183 Emma Goldman and Alexander Berkman, “Our Sixth Birthday,” Mother Earth 6, no. 1 (1911). Accessed September 1, 2020. http://dwardmac.pitzer.edu/Anarchist_Archives/goldman/ME/ mev6n1.html.

184 Glassgold, "Introduction," xvii.

185 See, for example, the evaluation of Kurt Eisner-a socialist German journalist and later Bavarian Prime Minister-in 1902 in "Sonntagsplauderei," Unterhaltungsblatt des Vorwärts 33, February 16, 1902: 130 -131, in Stiftung Archiv der Parteien und Massenorganisationen der DDR im Bundesarchiv (BArch-SAPMO), NY 4060/34, Ausarbeitungen von K.E., Artikel/Sonntagsplaudereien, 221-222. 
but she also sought "to precipitate and model a revolutionary mood for the women of her time." 186 It was the First World War that would eventually turn the tide, as Goldman criticized the government at a time when the latter was interested in inner stability and would not accept critical voices against the war, especially since the Russian Revolution had shown how the masses could react due to the pressure the war had put on the Czarist Empire. Berkman, Goldman, and other anarchists fell prey to the first Red Scare that was stimulated by the Russian Revolution during the war. Goldman, as Martha Solomon has highlighted, "was already a controversial figure, but her outspoken opposition to war and the draft excited further public outrage against her." ${ }^{87}$ Goldman's criticism against the First World War was, however, not surprising, as she not only "felt that war further enslaved workers as it enriched masters," ${ }^{188}$ but she, like many other left intellectuals, was shocked by the fact that the international workers' movement had lost its internationalist ideals and had turned into a nationalist vicarious agent of its imperialist governments. ${ }^{189}$

During the war, as well as in the years before, Goldman had always fought for free speech and against the attempts of the government to repress critical voices, especially since, as Vivian Gornick formulated so well, "the right to think and speak freely had always been the first article of faith nailed to Emma Goldman's front door."190 The famous anarchist was involved in the activities of the Free Speech League, which was founded in 1902, and protested against the Criminal Anarchy Act of the same year, which prohibited anarchist expressions, be they oral or written, made them illegal, and threatened felons with up to ten years in prison or a fine of up to $\$ 5,000 .{ }^{191}$ As anarchism was considered a foreign problem by the American public, the law also allowed for foreign radicals to be deported, although only 20 anarchists fell victim to the law between 1904 and 1916, including the English-born anarchist John Turner (1865-1934), who was the first to be "thrown out" of the US. ${ }^{192}$ Regardless of the law, anarchists con-

186 Hemmings, "In the Mood for Revolution," 528.

187 Solomon, Emma Goldman, 28.

188 Ibid.

189 For a survey of the protests by left intellectuals, see Frank Jacob and Riccardo Altieri, eds., Krieg und Frieden im Spiegel des Sozialismus 1914-1918 (Berlin: Metropol, 2018).

190 Gornick, Emma Goldman, 2.

191 Kraut, “Global Anti-Anarchism,” 177-178.

192 Ibid., 181-186. See also Sidney Fine, “Anarchism and the Assassination of McKinley,” The American Historical Review 60, no. 4 (1955): 777-799. Goldman later commented on Turner's fate as follows: "Turner was given the honour of being the first to fall under the ban of the Federal Anti-Anarchist Law passed by Congress on March 3, 1903. Its main section reads: 'No person who disbelieves in or who is opposed to all organized governments, or who is a member of or affili- 
tinued their work, and Goldman hoped that the masses would eventually realize that anarchism offered them a better life; the only thing that needed to be destroyed was the state. Although the police did everything possible to restrict Goldman from speaking about such ideas, the charismatic anarchist woman continued her work as a speaker and later as a publicist. ${ }^{193}$ Together with the Free Speech League in 1908/9, Goldman fought back against the police and the governmental authorities, demanding that freedom of speech be protected, even for anarchists. ${ }^{194}$

"Red Emma," as the more conservative press would call Goldman, "made this diminutive, slightly stout and now middle-aged, chain-smoking Russian immigrant appear to be a threat to the social order. To many of her detractors, 'Red Emma' was synonymous with bomb throwing, political assassination, and free love." 195 In the years leading up to the First World War, Goldman worked with the Free Speech League, the IWW, and many other labor unions or organizations to contest the state's attempt to prevent people from using their right to speak their mind freely and to express ideas, especially those related to anarchism and revolution. Goldman, like others, challenged the state's strategies in all possible forms, including "in a vocal libertarian press, on the streets, and in the courts." 196 Due to her central position within these Free Speech Fights in the early 20th century, ${ }^{197}$ Goldman even intensified her image as a radical anarchist-which was not only due to her more than 40 arrests between the 1890s and $1919^{198}$-who was almost notoriously challenging the state and its authorities, demanding an end to capitalist exploitation, the freedom of women and their sexuality, as well as the beginning of a world revolution on American soil. In terms of the latter, observations of the events in Russia in March 1917 seemed to be promising, and since revolutions were often "the result of crisis

ated with any organization entertaining or teaching such disbelief in or opposition to all governments ... shall be permitted to enter the United States.' John Turner, well known in his own country, respected by thinking people and having access to every European land, was now to be victimized by a statute conceived in panic and sponsored by the darkest elements in the United States. When I announced to the audience that John Turner had been arrested and would be deported, the meeting unanimously resolved that if our friend had to go, it should not be without a fight." Living My Life, ch. 27.

193 Lynskey, "I Shall Speak in Philadelphia," 167.

194 Ibid., 187-190.

195 Ibid., 168.

196 Ibid.

197 Philip S. Foner, ed., "Fellow Workers and Friends": I.W.W. Free-Speech Fights as Told by Participants (Westport, CT: Greenwood Press, 1981).

198 Lynskey, "I Shall Speak in Philadelphia," 172. 
conditions and insurrections, revolution embraces confrontation with the old order," ${ }^{199}$ it was not only the anarchists who had identified the political potential that the conflict between the government and anti-war activists in the United States provided. The revolutionary hopes of American radicals were also stimulated by the Russian Revolution, which was initially perceived as an important event in world history that could actually prove that capitalism could be replaced by a better society, and it was also admired by Goldman, whose "romantic commitment to an impossibly utopian ideal,"200 as Lori J. Marso quite negatively described it, was responsible for an initially rather uncritical view of the Russian events.

The US government, on the other hand, feared the Russian example gaining domestic support and consequently needed to contain any revolutionary potential, which forced it to counter the anarchist activities of Goldman and her circle in particular. With hundreds of radicals sent abroad, partially destroyed networks, and the rise of communism after 1917, the anarchist movement lost much of its influence and steadily declined after 1918. ${ }^{201}$ Although Goldman had hoped for a revolution on US soil, her deportation left her no other choice than to hope to become a part of the post-revolutionary effort to build a new society in Russia, but the realities of Lenin's political order "nearly broke her heart." ${ }^{202}$ As a revolutionary, Goldman would be disappointed in many ways, or, to cite Kathy E. Ferguson once more, "she loved her revolutions in the same extraordinary way she loved her partners, they disappointed her in the same devastating way, and in that same stubborn way she reconsidered her experience while refusing to surrender her ideal of what could be."203 Regardless of her eventual disappointment, Goldman admired the Bolshevists and the Russian Revolution at first, as she believed that her dream of revolutionary change had come true. Russia's masses had forced the Czar out of power, and they now had the possibility to build a new world from scratch, to forge a new society. Her admiration was enough for her to finally accept her fate, i.e. to be deported from the shores of the country she had had such high hopes for since she arrived in the 1880s. But the Russian realities would soon turn admiration into frustra-

199 Dana M. Williams, “Tactics: Conceptions of Social Change, Revolution, and Anarchist Organisation," in The Palgrave Handbook of Anarchism, ed. Carl Levy and Matthew S. Adams (Cham: Palgrave Macmillann, 2019), 108.

200 Marso, "The Perversions of Bored Liberals," 123-124.

201 McKinley, "The Quagmires of Necessity," 512.

202 Ferguson, "Gender and Genre," 752. See also Paul Avrich, Anarchist Voices: An Oral History of Anarchism in America (Oakland, CA: AK Press, 2005), 198.

203 Ferguson, "Gender and Genre," 753. 
tion. This transformative process shall now be taken into closer consideration, and Goldman's change from an enthusiastic revolutionary to a fierce anti-Bolshevist will be described and analyzed in more detail. 
